\title{
Akuntabilitas Pengelolaan Keuangan Desa Berdasarkan Filosofi Tri Hita Karana di Desa Buduk, Kecamatan Mengwi, Kabupaten Badung
}

\author{
I Gusti Ayu Astri Pramitari ${ }^{1}$ \\ Jurusan Akuntansi \\ Politeknik Negeri Bali, Indonesia
}

\author{
Ketut Nurhayanti ${ }^{2}$ \\ Jurusan Akuntansi \\ Politeknik Negeri Bali, Indonesia
}

\begin{abstract}
Surel : astripramitari@pnb.ac.id
ABSTRAK

Penelitian ini bertujuan untuk mendeskripsikan akuntabilitas pengelolaan keuangan berdasarkan filosofi Tri Hita Karana di Desa Buduk. Jenis pendekatan penelitian yang digunakan adalah penelitian kualitatif dengan metode etnometodologi. Metode pengumpulan data yang digunakan adalah wawancara, observasi dan dokumentasi. Hasil penelitian ini menunjukkan bahwa Pemerintah Desa Buduk telah melaksanakan pengelolaan keuangan dengan akuntabel berdasarkan filosofi Tri Hita Karana ,yang dapat dilihat dari akuntabilitas terhadap Tuhan (Parahyangan), akuntabilitas terhadap masyarakat (Pawongan), dan akuntabilitas terhadap lingkungan (Palemahan).
\end{abstract}

Kata Kunci: Akuntabilitas; Keuangan Desa; Laporan Keuangan; Tri Hita Karan.

\section{Village Financial Management Accountability Based on the Tri Hita Karana Philosophy in Buduk Village, Mengwi District, Badung Regency}

\footnotetext{
ABSTRACT

This research was conducted to understand financial management in Buduk Village based on the Tri Hita Karana philosophy. This research uses qualitative approach with ethnomethodology method. The data was collected by interview, observation, and documentation. The results of this study indicate that the Buduk Village Government has implemented accountable financial management based on the Tri Hita Karana philosophy, which can be seen from accountability to God (Parahyangan), accountability to the community (Pawongan) and accountability to the environment (Palemahan).
}

Keywords: Accountability; Financial Reporting; Village Fund; Tri Hita Karana.

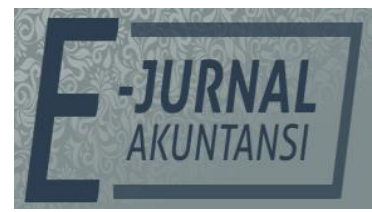

e-ISSN 2302-8556

Vol. 30 No. 11

Denpasar, Nopember 2020 Hal. 2959-2968

DOI: 10.24843/EJA.2020.v30.i11.p18

PENGUTIPAN:

Pramitari, I G.A.A. \&

Nurhayati, K. (2020). Akuntabilitas Pengelolaan Keuangan Desa Berdasarkan Filosofi Tri Hita Karana di Desa Buduk, Kecamatan Mengwi, Kabupaten Badung. E-Jurnal Akuntansi, 30(11), 2959-2968

RIWAYAT ARTIKEL:

Artikel Masuk: 27 Oktober 2020 Artikel Diterima: 27 November 2020

Artikel dapat diakses : https://ojs.unud.ac.id/index.php/Akuntansi/index 


\section{PENDAHULUAN}

Pemerintah Indonesia melakukan berbagai upaya guna mempercepat proses pembangunan nasional. Pembangunan Nasional tidak dapat tercapai tanpa adanya pemerataan pembangunan di seluruh wilayah Indonesia, yang dapat dimulai dari pembangunan desa. Salah satu upaya yang dilakukan Pemerintah adalah dengan menerbitkan Undang-Undang Nomor 6 Tahun 2014 tentang Desa. Lahirnya Undang-Undang tentang Desa ini memberikan kesempatan bagi Desa untuk terus berkembang, salah satunya dengan melakukan pengelolaan keuangannya sendiri yang bersumber dari pemerintah daerah serta pendapatan lainnya.

Berdasarkan Undang-Undang Nomor 6 Tahun 2014 proses pengelolaan keuangan Desa terdiri dari beberapa kegiatan utama antara lain kegiatan perencanaan, pelaksanaan, penatausahaan, dan pertanggungjawaban keuangan (Undang - Undang no 6 Tahun 2014, 2014). Kondisi desa yang semakin otonom memberikan dampak yang positif bagi masyarakat, namun di sisi lain terdapat kekhawatiran terkait pengelolaan keuangan desa tersebut. Besarnya dana yang dikelola desa menimbulkan kekhawatiran terkait kesiapan desa dalam melakukan pengelolaan keuangan (Pramayoga \& Ramantha, 2020).

Kompetensi Aparatur Desa menjadi hal yang sangat penting guna mencapai pengembangan Desa yang optimal (Anto \& Amir, 2017). Aparatur Desa sebagai pihak pengelola keuangan harus memiliki kemampuan yang memadai dalam menyusun perencanaan keuangan, proses pelaksanaan/penggunaan anggaran keuangan serta memahami sistem akuntansi yang baik, sehingga dapat mewujudkan akuntabilitas pengelolaan keuangan yang baik kepada publik (Nyimas Latifah Letty Aziz, 2016).

Akuntabilitas merupakan alat kontrol utama untuk mengetahui keberhasilan pelayanan pemerintah kepada publik (Cindy, Salle, \& Andika Rante, 2018). Akuntabilitas mampu terwujud dengan dilaksanakannya praktikpraktik transparansi, kejujuran, integritas dan konsistensi (Sari \& Sudana, 2020). Kebebasan dalam berpendapat, transparansi dan suasana yang demokratis merupakan kunci utama terwujudnya akuntabilitas kepada publik (M.M Ludani, G.B Tampi, 2017). Publik memiliki hak untuk mengetahui berbagai kebijakan yang diambil oleh pemerintah setempat.

Permasalahan yang seringkali muncul terkait dengan akuntabilitas adalah pertanggungjawaban yang diberikan belum sesuai dengan apa yang diinginkan oleh masyarakat, serta kurang menekankan pada akuntabilitas bagi publik dan masyarakat luas, selain itu laporan pertanggungjawaban yang dibuat juga belum mengikuti standar serta rawan manipulasi (Hasniati, 2016). Salah satu faktor yang dapat mendukung terciptanya akuntabilitas adalah budaya dan adat istiadat di suatu daerah (Kurniawan, 2016). Dalam ajaran Agama Hindu di Bali dikenal sebuah konsep yang merupakan harmonisasi hubungan antara masyarakat di Bali yang selalu dijaga baik dengan Tuhan (Parahyangan), sesama manusia (Pawongan), dan dengan lingkungan (Palemahan) (Riana, 2010). Budaya Kejujuran, Keterbukaan dan Pencegahan segala kecurangan dalam mewujudkan akuntabilitas publik mampu tercipta melalui hadirnya konsep religiusitas Tri Hita Karana (Saputra, 2012). 
Budaya Tri Hita Karana mampu meningkatkan kinerja keuangan suatu organisasi, karena budaya merupakan hal yang telah mengakar dan diadopsi masyarakat yang telah tertanam sejak dahulu kala (Suarna Bumi, 2019). Terdapat beberapa penelitian terkait pengaruh budaya Tri Hita Karana dalam pengelolaan keuangan sebuah organisasi di Bali, (Sedani et al., 2019) dalam penelitiannya memperoleh hasil bahwa budaya Tri Hita Karana berpengaruh terhadap pengelolaan keuangan di desa Antuan yang ditunjukkan dengan berbagai kegiatan yang dilaksanakan oleh pengurus Desa dengan alokasi dana sebesar $15 \%$ untuk parahyangan, $70 \%$ untuk pawongan dan pawongan $15 \%$. Tri Hita Karana juga diimplementasikan dalam pelaksanaan corporate social responsibility pada LPD Kuta dan menghasilkan tiga sinergi implementasi yakni implementasi masyarakat, lingkungan dan hal-hal yang berkaitan dengan Tuhan (Purwati \& Tenaya, 2018). Dampak Tri Hita Karana dalam pengelolaan keuangan adalah kegiatan menjadi lebih mudah dilaksanakan dengan adanya pengelompokan berdasarkan unsur-unsur Tri Hita Karana (Meitriani, Atmadja, Eka, Marvilianti, \& Ganesha, 2017).

Desa Buduk berada di Kecamatan Mengwi, Kabupaten Badung. Sejak berlakunya UU Nomor 6 Tahun 2014, Desa Buduk memiliki kewenangan untuk melaksanakan pengelolaan keuangannya secara mandiri. Berdasarkan data yang diperoleh dari pengelola keuangan di Desa Buduk, besarnya anggaran pendapatan yang dikelola di tahun 2019 adalah sebesar Rp12.939.617.143,00 yang bersumber dari pendapatan asli desa, pendapatan transfer dan pendapatan lainlain. Jumlah anggaran yang cukup besar ini harus mampu dikelola dengan baik oleh aparatur desa dengan tujuan untuk memberikan kesejahteraan kepada masyarakat di desa Buduk dan mewujudkan terciptanya pembangunan Nasional, sehingga diperlukan akuntabilitas dari Pemerintah Desa Buduk dalam pengelolaan keuangan desa. Masyarakat Desa Buduk dalam aktivitas kesehariannya menjalankan konsep Tri Hita Karana sebagai konsep luhur yang telah berakar pada kehidupan masyarakat di Bali. Berdasarkan penjabaran latar belakang, maka dapat disuse dengan kerangka konseptual sebagai berikut.

Akuntabilitas Pengelolaan Keuangan Desa:

Transparansi, kejujuran, integritas, keadilan, dan konsistensi

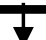

Tri Hita Karana:

Parahyangan, Pawongan dan Palemahan

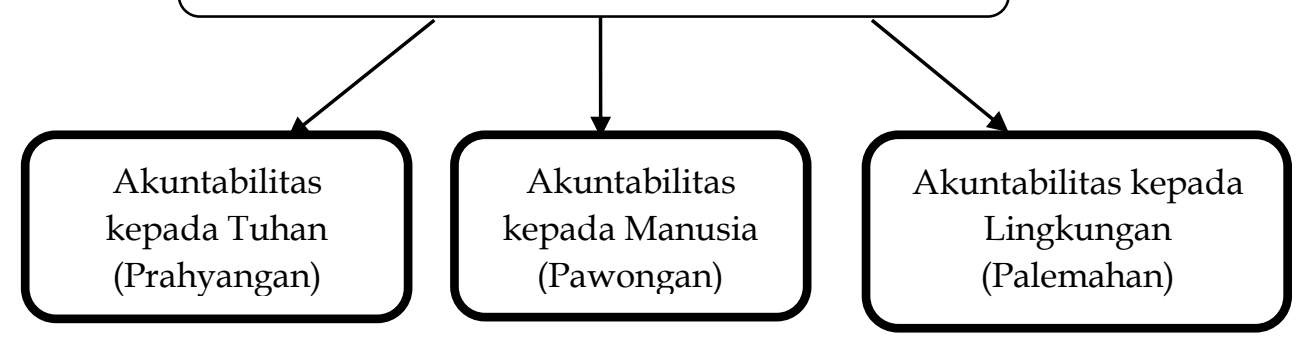

Gambar 1. Kerangka Konseptual Penelitian

Sumber: Data Penelitian, 2020 
Rumusan Masalah dari penelitian ini adalah bagaimana akuntabilitas pengelolaan keuangan desa di Desa Buduk berdasarkan Filosofi Tri Hita Karana? Tujuan dari penelitian ini adalah mendeskripsikan akuntabilitas pengelolaan keuangan desa di Desa Buduk berdasarkan filosofi Tri Hita Karana.

\section{METODE PENELITIAN}

Desain penelitian yang digunakan dalam penelitian ini adalah pendekatan kualitatif dengan metode analisis deskriptif. Dalam penelitian kualitatif sangat ditekankan pemahaman terhadap suatu temuan yang diperoleh dari tempat penelitian (Sujana, et al., 2017). Pendekatan Etnomedologogi digunakan dalam penelitian ini untuk mendapatkan pemahaman bagaimana unsur-unsur budaya diterapkan dalam kehidupan sehari-hari (Susilo, 2017). Lokasi penelitian dilakukan di Kantor Perbekel Desa Buduk, Kecamatan Mengwi, Kabupaten Badung. Metode studi kasus digunakan dalam penelitian ini guna memberikan pandangan terkait akuntabilitas pengelolaan keuangan Desa Buduk berdasarkan filosofi Tri Hita Karana.

Analisis data pada penelitian ini dilakukan melalui : (a) Pengumpulan data, pada tahap pertama dilakukan pengumpulan data dengan menggunakan teknik wawancara kepada informan yang memahami pengelolaan keuangan di Desa Buduk serta dilakukan observasi lingkungan Desa Buduk. Data sekunder diperoleh dari hasil dokumentasi laporan pertanggungjawaban keuangan Pemerintah Desa Buduk, (b) Pengelompokan data, proses berikutnya adalah dengan pengelompokkan data yang telah diperoleh dari hasil wawancara, observasi serta dokumentasi terhadap laporan pertanggungjawaban keuangan Pemerintah Desa Buduk, (c) Reduksi data, dalam proses ini dilakukan pemilihan serta penyederhanaan data yang sebelumnya telah dikelompokkan oleh peneliti peneliti, (d) Penyajian data, yakni data hasil wawancara disajikan dalam bentuk uraian terkait akuntabilitas pengelolaan keuangan Desa Buduk dengan penerapan nilai filosofis Tri Hita Karana, (e) Interpretasi data dan penarikan kesimpulan, setelah dilakukan penyajian data, kemudian data tersebut dianalis dan dilakukan penarikan kesimpulan atas hasil yang didapatkan.

\section{HASIL DAN PEMBAHASAN}

Desa Buduk terletak di Kecamatan Mengwi, Kabupaten Badung, Provinsi Bali. Berdasarkan data yang diperoleh dari pengelola keuangan di Desa Buduk, besarnya anggaran yang dikelola di tahun 2019 adalah sebesar Rp12.939.617.143,00 yang berasal dari berbagai sumber pendapatan antara lain: pendapatan asli desa, pendapatan transfer, dan pendapatan lain-lain. Dalam rangka mempertanggungjawabkan anggaran yang telah ditetapkan, aparatur Desa Buduk telah membuat laporan pertanggungjawaban keuangan yakni Laporan Pelaksanaan Anggaran Pendapatan dan Belanja Desa Semester Akhir Tahun 2019. Penelitian ini mengkaji bagaimana akuntabilitas dalam pengelolaan keuangan desa berdasarkan filosofi Tri Hita Karana yang merupakan sebuah konsep Hindu yang menggambarkan harmonisasi hubungan antara manusia 
dengan Tuhan (Parahyangan), manusia dengan sesama (Pawongan) dan manusia dengan alam semesta serta lingkungan sekitarnya (Palemahan).

Berdasarkan penjabaran, maka dilakukan kajian terkait bagaimana akuntabilitas pengelolaan keuangan desa berdasarkan unsur Parahyangan, akuntabilitas pengelolaan keuangan desa berdasarkan unsur Pawongan serta akuntabilitas pengelolaan keuangan desa berdasarkan unsur Palemahan.

Konsep Parahyangan dapat diwujudkan melalui keyakinan terhadap keberadaan Tuhan. Perwujudan dari adanya keyakinan para aparatur Desa Buduk terhadap keberadaan Tuhan Yang Maha Esa yakni dengan selalu bekerja keras untuk melayani masyarakat desa, mematuhi peraturan yang berlaku serta selalu mengutamakan kepentingan publik sebagai wujud pengabdian diri kepada Tuhan Yang Maha Esa. Kejujuran dan Integritas dari Aparatur Desa juga merupakan wujud dari pelaksanaan konsep Parahyangan di Desa Buduk.

Penerapan prinsip transparansi dalam pengelolaan keuangan Desa dilakukan dengan cara mengadakan musyawarah desa guna menghimpun aspirasi masyarakat Desa terkait rencana penggunaan anggaran di Tahun berikutnya. Sebelum dilaksanakannya kegiatan musyawarah, dilakukan kegiatan "Matur Piuning" di Padmasana Kantor Perbekel agar kegiatan musyarawah berjalan dengan lancar. Kegiatan matur piuning dan persembahyangan bersama juga dilakukan secara rutin sebelum melaksanakan aktivitas lainnya yang berkaitan dengan pelaksanaan anggaran tahunan Desa. Aparatur Desa Buduk sangat menghargai dan menghormati pelaksanaan upacara kegamaan, dengan memberikan disepensasi bagi para pegawai atau aparatur desa saat ada prosesi keagamaan di Desa. Akuntabilitas terkait dengan unsur parahyangan juga tercermin dalam kegiatan keagamaan dan pembangunan fasilitas tempat ibadah di Lingkungan Desa Buduk. Bapak Wayan Sudarsana selaku Sekretaris Desa Buduk menyampaikan sebagai berikut.

“Setiap Tahunnya selalu dianggarkan sejumlah dana guna membantu pemugaran pura maupun tempat ibadah lainnya di lingkungan Desa Buduk, agar dapat melancarkan kegiatan beribadah masyarakat, selain itu penggunaan anggaran desa juga dialokasikan pada pembelian banten dan upakara lainnya seperti upakara Ngenteg Linggih yang dilaksanakan di Padmasana Kantor Perbekel, dan banten upakara terkait pembangunan PAUD yang baru"

Dalam Laporan Pelaksanaan Anggaran Pendapatan dan Belanja Desa Semester Akhir Tahun 2019 dapat dilihat terdapat beberapa pengeluaran dana untuk kegiatan-kegiatan yang berhubungan dengan upacara keagamaan yang dilakukan di lingkungan Desa Buduk serta pemugaran bangunan tempat ibadah/pura, besarnya anggaran yang ditetapkan di tahun 2019 terkait dengan kegiatan yang berhubungan dengan upacara keagamaan adalah sebesar Rp357.103.745,00 dengan realisasi sebesar Rp323.531.900,00.

Unsur Pawongan dalam lingkungan pemerintahan desa terkait dengan pengelolaan keuangannya diwujudkan dalam bentuk hubungan yang baik dengan masyarakat. Unsur pawongan juga menggambarkan prinsip pelaksanaan anggaran yang adil sebab kegiatan dilaksanakan kepada seluruh aspek masyarakat. Sebagai bentuk transparansi pengelolaan keuangan Desa, Aparatur Desa Buduk wajib mempublikasikan anggaran tahunannya kepada masyarakat 
desa. Masyarakat Desa memiliki hak untuk mengetahui sumber pendandaan, program yang dilaksanakan pemerintah Desa pada setiap tahun anggaran, tujuan pelaksanaan program, proses pelaksanaan kegiatan, serta dan pertanggungjawabannya.

Pertanggungjawaban kepada masyarakat menjadi hal yang penting sebab masyarakat telah mempercayakan pengelolaan keuangan desa melalui perwakilan aparatur desa. Forum Sangkep rutin dilaksanakan sebagai sarana penyampaian informasi terkait dengan penggunaan keuangan desa sehingga dapat dipantau oleh seluruh aspek masyarakat di Desa.

Dalam Laporan Pelaksanaan Anggaran Pendapatan dan Belanja Desa Semester Akhir Tahun 2019 dapat dilihat terdapat beberapa pengeluaran dana untuk kegiatan-kegiatan yang berhubungan dengan peningkatan kesejahteraan masyarakat di Desa yang terbagi atas beberapa sub kegiatan seperti sub bidang Pendidikan yakni dengan pembangunan PAUD, pemberian beasiswa bagi siswa miskin dan siswa berprestasi, sub bidang Kesehatan yakni dengan penyelenggaraan Pos Kesehatan Desa, Posyandu, Bina Keluarga Balita, sub bidang Kawasan pemukiman yakni dengan kegiatan rehabilitasi fasilitas pendukung pemukiman seperti lapangan, serta sanitasi yang memadai untuk MCK, sub bidang perhubungan yang bertujuan sebagai penyampaian informasi yang transparan kepada publik, sub bidang pembinaan kemasyarakatan dengan mendirikan pos keamanan desa, dan program tanggap bencana, sub bidang kebudayaan dan keagamaan terkait dengan pengembangan kemampuan berkesenian masyarakat desa termasuk juga pengembangan kesenian anggota masyarakat yang difabel, sub bidang kepemudaan dan olahraga dengan kegiatan-kegiatan pengembangan kemampuan olahraga, pembinaan STT dan juga PKK. Besarnya anggaran di Tahun 2019 terkait dengan kegiatan yang berhubungan dengan kesejahteraan masyarakat desa adalah sebesar Rp9.672.884.817,00 dengan realisasi sebesar Rp7.480.629.394,00

Sebagai upaya mensejahterakan masyarakat, Desa Buduk juga telah membangun Badan Usaha Milik Desa (BUMDes). BUMDes diharapakan dapat menjadi penghubung antara Desa dengan perekonomian di luar Desa dan sebagai penguat ekonomi di pedesaan. BUMDes yang dibangun di Desa Buduk bertujuan untuk meningkatkan kemandirian masyarakat desa khususnya di Bidang Ekonomi melalui pengembangan potensi Desa yang terbagi atas 6 unit usaha yakni: Unit Simpan Pinjam, Unit Jasa Penyewaan Tempat Baliho, Unit Jasa Pembayaran Online, Unit Jasa Transport, Unit Dagang dan Unit Jasa Pengelolaan Sampah. Hanya saja dalam hal pengelolaan BUMDes masih perlu banyak perbaikan khususnya dari segi pertanggungjawban keuangan BUMDes yang pencatatannya masih sangat sederhana.

Palemahan merupakan konsep hubungan manusia dengan alam, manusia diharapkan memiliki tanggung jawab pada alam dalam mengelola alam tersebut. Kepedulian Aparatur Desa terhadap lingkungan sebagai wujud keharmonisan lingkungan sesuai dengan konsep Palemahan diwujudkan dalam berbagai kegiatan yang dilakukan baik kegiatan internal aparatur Desa maupun kegiatan yang dilaksanakan secara bersama-sama dengan masyarakat Desa. Aparatur Desa rutin melakukan kegiatan gotong royong dengan masyarakat sekitar guna membersihkan lingkungan desa. Dalam laporan 
pertanggungjawaban keuangan desa juga terdapat beberapa penggunaan dana untuk melestarikan lingkungan seperti gotong royong, pembangunan goronggorong untuk mencegah banjir, pemugaran fasilitas termasuk penanaman pohon di lingkungan kantor Desa dan lingkungan Desa Buduk.

Akuntabilitas Pengelolaan Keuangan Desa di Desa Buduk berdasarkan filosofi Tri Hita Karana dapat dikonseptualisasi dalam bentuk tabel berikut.

Tabel 1. Akuntabilitas Pengelolaan Keuangan Desa di Desa Buduk berdasarkan filosofi Tri Hita Karana

\begin{tabular}{|c|c|c|c|}
\hline No & $\begin{array}{l}\text { Aspek Tri } \\
\text { Hita Karana }\end{array}$ & Kegiatan & Nilai Akuntabilitas \\
\hline 1 & $\begin{array}{c}\text { Tuhan } \\
\text { (Parahyangan) }\end{array}$ & $\begin{array}{l}\text { 1. Matur Piuning sebelum } \\
\text { melaksanakan segala kegiatan di } \\
\text { Desa } \\
\text { 2. Mematuhi Segala peraturan } \\
\text { yang ditetapkan } \\
\text { 3. Pembangunan ataupun } \\
\text { pemugaran fasilitas ibadah bagi } \\
\text { masyarakat }\end{array}$ & $\begin{array}{c}\text { Kejujuran,integritas } \\
\text { transparansi, adil } \\
\text { dan konsistensi }\end{array}$ \\
\hline 2 & $\begin{array}{l}\text { Masyarakat } \\
\text { (Pawongan) }\end{array}$ & $\begin{array}{l}\text { 1. Pelaksanaan Sangkep sebagai } \\
\text { sarana penyampaian informasi } \\
\text { terkait dengan penggunaan } \\
\text { keuangan desa sehingga dapat } \\
\text { dipantau oleh seluruh aspek } \\
\text { masyarakat di Desa. } \\
\text { 2. Kegiatan-kegiatan untuk } \\
\text { mensejahterakan masyarakat } \\
\text { baik dari aspek Pendidikan, } \\
\text { kesehatan, pemukiman, dan } \\
\text { lain-lain } \\
\text { 3. Penyusunan Laporan Keuangan } \\
\text { sebagai bentuk } \\
\text { pertanggungjawaban } \\
\text { penggunaan anggaran } \\
\text { 4. Pembangunan Badan Usaha } \\
\text { Milik Desa }\end{array}$ & $\begin{array}{l}\text { Transparansi, adil } \\
\text { dan konsisten }\end{array}$ \\
\hline 3 & $\begin{array}{l}\text { Lingkungan } \\
\text { (Pawongan) }\end{array}$ & $\begin{array}{l}\text { 1. Pelaksanaan kegiatan gotong } \\
\text { royong } \\
\text { 2. Pembangunan Tempat } \\
\text { Pengelolaan Sampah Terpadu } \\
\text { (TPST) }\end{array}$ & $\begin{array}{l}\text { Transparansi, adil } \\
\text { dan konsisten }\end{array}$ \\
\hline
\end{tabular}


Aparatur Desa Buduk melalui salah satu unit usahanya yakni unit pengelolaan sampah juga turut serta melestarikan lingkungan dengan mengurangi dampak buruk yang muncul akibat adanya penumpukan sampah. Badan Usaha Milik Desa Buduk yang terletak di Desa Buduk ini mengelola sendiri sampah yang ada di masyarakat dalam wadah TPST yang berada di wilayah Desa Buduk, yang merupakan satu-satunya TPST mandiri di Kecamatan Mengwi. Kegiatan yang dilakukan adalah dengan mengambil sampah setiap rumah tangga pada masing-masing banjar di wilayah Desa Buduk. Sampah yang diangkut kemudian dikumpulkan di TPST dan kemudian dipilah berdasarkan jenisnya. Sampah organik dihancurkan dengan media maggot yang saat ini sedang dikembangkan oleh BUMDes Buduk "Buduk Mitra Winangun" sebagai pengurai sampah organik yang efektif. Sampah anorganik recyclable dipilah dan kemudian diserahkan kepada Dinas Lingkungan Hidup dan Kebersihan (DLHK) Kabupaten Badung, sedangkan sampah anorganik non-recyclable dieliminasi menggunakan mesin pencacah dan dibakar menggunakan kompor.

\section{SIMPULAN}

Berdasarkan hasil penelitian yang telah dilakukan maka dapat disimpulkan bahwa Aparatur Desa Buduk dalam pengelolaan keuangannya telah melaksanakan akuntabilitas berdasarkan filosofi Tri Hita Karana. Pengelolaan Keuangan di Desa Buduk telah mencerminkan prinsip-prinsip akuntabilitas antara lain kejujuran, intergritas, keadilan, transparansi dan konsistensi. Hal ini merupakan perwujudan filosifi Tri Hita Karana yang dianut oleh pengurus maupun masyarakat di Desa Buduk. Dalam Laporan Pelaksanaan Anggaran Pendapatan dan Belanja Desa Semester Akhir Tahun 2019. Akuntabilitas Pengelolaan Keuangan Desa berdasarkan unsur Parahyangan diwujudkan dalam kegiatan sehari-hari aparatur Desa yang selalu menjalankan tugas sesuai dengan kepentingan publik dan bekerja keras mengutamakan kepentingan desa dan masyarakat sebagai wujud pengabdian diri kepada Tuhan Yang Maha Esa, selain itu dalam laporan pelaksanaan anggaran dan belanja desa tahun 2019 terdapat beberapa penggunaan dana untuk kegiatan yang berkaitan dengan pemugaran tempat ibadah maupun upacara keagamaan di lingkungan Desa.

Akuntabilitas Pengelolaan Keuangan Desa berdasarkan unsur Pawongan tercermin dari hubungan yang baik antara aparatur desa dengan masyarakat di Desa Buduk. Forum Sangkep rutin dilaksanakan sebagai sarana penyampaian informasi terkait dengan penggunaan keuangan desa sehingga dapat dipantau oleh seluruh aspek masyarakat di Desa. Berbagai kegiatan juga telah dilaksanakan dengan menggunakan anggaran desa guna meningkatkan kesejahteraan masyarakat. Akuntabilitas Pengelolaan Keuangan Desa berdasarkan unsur Palemahan tercermin dari kepedulian terhadap lingkungan dengan rutinnya pelaksanaan kegiatan gotong royong dengan masyarakat sekitar guna membersihkan lingkungan desa. Dalam laporan pertanggungjawaban keuangan desa juga terdapat beberapa penggunaan dana untuk melestarikan lingkungan seperti gotong royong, pembangunan goronggorong untuk mencegah banjir, pemugaran fasilitas termasuk penanaman pohon di lingkungan kantor Desa dan lingkungan Desa Buduk, selain itu salah satu 
BUMDes Desa Buduk juga melakukan kegiatan usaha pengelolaan sampah masyarakat guna melestarikan lingkungan.

Saran yang dapat diberikan kepada pengelola keuangan Desa Buduk adalah untuk menambah pengetahuan terkait sistem pencatatan akuntansi yang digunakan agar mampu menghasilkan laporan keuangan yang lebih informatif. Adapun keterbatasan dari penelitian ini adalah waktu yang singkat mengakibatkan kurang terperincinya wawancara dan observasi yang dilakukan sehingga saran bagi peneliti berikutnya adalah untuk menambah Narasumber penelitian dan observasi lapangan sehingga hasil yang diperoleh lebih mendetail serta memperluas cakupan penelitian yang dilakukan.

\section{REFRENSI}

Anto, R. P., \& Amir, M. (2017). Competence of Village Apparatus In Management of Village Funds in North Konawe Regency-Indonesia. IOSR Journal of Business and Management.

Cindy, A., Salle, D. A., \& Andika Rante. (2018). Pengaruh Akuntabilitas, Transparansi dan Pengawasan terhadap Kinerja Anggaran Berbasis Value For Money. Akuntansi \& Keuangan Daerah.

Hasniati. (2016). Model Akuntabilitas Pengelolaaan Dana Desa. Jurnal Analisis Kebijakan Dan Pelayanan Publik.

Kurniawan, P. S. (2016). Peran Adat Dan Tradisi Dalam Proses TRansparansi Dan Akuntabilitas Pengelolaan Keuangan Desa Pakraman. Seminar Nasional Riset Inovatif (Senari).

M.M Ludani, G.B Tampi, J. P. (2017). Akuntabilitas Dalam Pengelolaan Keuangan Daerah ( Suatu Studi Pada Dinas Pendapatan Daerah Kabupaten Banggai Kepulauan ). Jurnal Akuntansi Pemerintahan.

Meitriani, A., Atmadja, T., Eka, P., Marvilianti, D., \& Ganesha, U. P. (2017). Mengungkap Praktik Akuntabilitas Pengelolaan Keuangan Berlandaskan Konsep Tri Hita Karana Pada Desa Pakraman ( Studi Kasus Pada Desa Pakraman Dharmajati, Tukadmungga ). E-Jurnal S1 Ak Universitas Pendidikan Ganesha.

Nyimas Latifah Letty Aziz. (2016). Otonomi Desa Dan Efektivitas Dana Desa. Jurnal Penelitian Politik. Https://Doi.Org/10.20885/Unisia.Vol27.Iss53.Art12

Pramayoga, I. B., \& Ramantha, I. W. (2020). Pengaruh Kejelasan Sasaran Anggaran, Kompetensi Aparatur Desa, Dan Kepemimpinan Pada Akuntabilitas Pengelolaan Dana Desa Di Kecamatan Gianyar. E-Jurnal Akuntansi. Https://Doi.Org/10.24843/Eja.2020.V30.I01.P17

Purwati, D. K. I., \& Tenaya, A. I. (2018). Implementasi Corporate Social Responsibility Berlandaskan Filosofi Tri Hita Karana Pada Lembaga Perkreditan Desa. E-Jurnal Akuntansi, 23, 2203. Https:/ / Doi.Org/10.24843/Eja.2018.V23.I03.P22

Sari, D. M. M. Y., \& Sudana, I. P. (2020). Managerial Accountability Of Badan Usaha Milik Desa Wija Sari In Samsam Village: A Case Study Research. Jurnal Ilmiah Akuntansi Dan Bisnis, 15(2), 152. Https://Doi.Org/10.24843/Jiab.2020.V15.I02.P02

Sedani, K. Y., Sukartini, N. K., Budiasih, K. J., Windiani, L. P., Yudiani, N. M., \& Laksmi, K. T. P. (2019). Analisis Pengaruh Tri Hita Karana Terhadap 
Pengelolaan Keuangan Desa Di Desa Anturan. Jurnal Ilmiah Akuntansi Dan Humanika. Https://Doi.Org/10.23887/Jinah.V8i1.19864

Susilo, D. (2017). Etnometodologi Sebagai Pendekatan Baru Dalam Kajian Ilmu Komunikasi. Jurnal Studi Komunikasi (Indonesian Journal Of Communications Studies). Https://Doi.Org/10.25139/Jsk.V1i1.66

Undang - Undang No 6 Tahun 2014. (2014). Undang-Undang Nomor 6 Tahun 2014 Tentang Desa. Undang - Undang No 6 Tahun 2014. Https://Doi.Org/10.1017/Cbo9781107415324.004 